REDAKTIONEN

3 Forord

Stranden

JOHN R. GILLIS

19 Den andre oppdagelsen av havet

FRITS ANDERSEN

39 Den allerede moderne strand

Robert Louis Stevensons stillehavsfortællinger

KATRINE HELENE ANDERSEN

63 Nydelsesturisme in extremis

Fra otium til masseturisme på de spanske strande

TORE RYE ANDERSEN

87 Sous la plage, les pavés!

Stranden mellem utopi og dystopi i nyere amerikansk litteratur

SUSANNE BANGERT

109 Den "danske friske strand" og 1800-tallets landskabsmaleri JEPPE BARNWELL

135 Livets mening på Lakolk strand

Horisontal fordomsfrihed i Peter Seebergs roman Ved havet

CHRISTIAN DAHL

161 Ét sted, to topoi

Stranden som blindgyde og kontaktzone i græsk antik digtning

KNUT OVE ELIASSEN

177 Strandens topologier

MARIUS WARHOLM HAUGEN

209 Stranden hos Elena Ferrante

SARAH DAHLE HERMANSTAD

239 Mellom vrak og strand

Vrakberging og liminalitet ved Hitra og Frøya på 1700- og 1800-tallet 


\section{CHRISTOPHER MESSELT}

259 Den norske litterære stranden

Anmeldelser

INGE LISE MOGENSEN BECH

283 Fortidens fysiognomi

Anmeldelse af Peer E. Sørensen: Modernismens Ansigter

TAKK

Fonden for dansk-norsk samarbeid bevilget en tredagerskonferanse for bidragsyterne på Lysebu konferansesenter, i desember 2019.

Institutt for språk og litteratur, Humanistisk fakultet, NTNU, Trondheim, bevilget penger til produksjon av boken.

From the high seas to the deep oceans, representations, resources and regulations, forskningsprosjekt ved NTNU, finansierte trykking av hefte og plakat.

FORSIDEN:

Simon Roberts: Blackpool Beach \#1, Lancashire, 2008. 


\section{FORORD}

\section{Stranden}

Fire fotografier kan stå som anslag for dette nummeret av K\&K - Kultur og klasse: afrikanske emigranter løpende mellom solbadere i Marbella; rustne supertankere strandet på rekke og rad i Bangladesh; en pelikan tildekket av oljesøl på Floridakysten; rustne indonesiske fiskebåter trukket opp på en strand fylt med plastavfall. Motivene peker på strandsonens aktualitet som scene for vår tids mest presserende spørsmål - migrasjon, tredje verden som søppeldestinasjon, forurensing og maritim kollaps. Samtidig er de uttrykk for kystkulturer i sterk endring. Utover å rapportere om en trist realitet synliggjør disse fotografiene - på verdensveven finnes de i mange varianter og kombinasjoner - hvordan økologisk, økonomisk og politisk konfliktstoff medieres og forhandles visuelt og litterært i en global offentlighet som i tiltagende grad merkes av det som har blitt betegnet den antropocene tilstand. Fotografiene mobiliserer etablerte estetiske figurer og troper som utstyrer dem med patos og betydning. Ved å fokusere "stranden" har det vært vår ambisjon å belyse hvordan estetiske artikulasjoner som disse henter retorisk kraft og politisk meningsinnhold fra et kulturelt fortolkningsrom med en kompleks historie.

Stranden har en sentral plass i den europeiske estetiske tradisjonen, i litteraturen og i de plastiske kunster, sågar i musikken. Like fullt er den lite 
studert, og den kulturelle hukommelsen synes hva strender angår, relativt kort. Man kan spekulere i hvorvidt denne mangelen skyldes at stranden nettopp i den grad har blitt opparbeidet som allmennsted - et locus communis, noe alle vet hva er, og derfor alltid velkjent og ureflektert. Et viktig unntak er etnografene som har viet stranden en god del oppmerksomhet, fortrinnsvis i form av undersøkelser av ikke-europeiske strandkulturer. Som etnografisk studieobjekt har den vært et privilegert sted til å utforske grensesnittene mellom kulturer. Ikke bare har strender den egenskap at de leverer klart definerte områder egnet til å studere former for sosial aktivitet, de er, med ett av Claude Levi-Strauss' munnhell, "gode til å tenke med". Således bemerker antropologen Michael Taussig i "The Beach (A Fantasy)" at strender er paradoksale ørkener (Taussig); de er ødemarker i ordets betydning av "ukultivert" og "ikke-bebodd". Strender både er øde og legger øde. Med Bruno Latours term er de "aktanter" i øde-leggende prosesser - fra erosjonen som har produsert sanden som definerer dem, til de ødelagte, råtnende og døde objektene som brenningen jevnlig etterlater på stranden.

For den etnografisk orienterte australske historikeren Greg Dening er stranden primært et møtested. I Beach Crossings omtaler han dem som "in-between spaces", rom for forvandling og for begivenheter. Denings bestemmelse av stranden fremhever dens karakter av å være preget av det man i den etnografiske tradisjonen etter Arnold van Gennep og Victor Turner betegner som "liminalitet". Strender er liminalsoner fordi de er terskler mellom det faste og det flytende, land og vann, og de er derfor underlagt andre regler (Dening 16). Å krysse stranden er å bevege seg fra en verden til en annen, å forflytte seg mellom forskjellige ontologiske realiteter. Kulturelt preget og avgrenset som en annen type rom, merker stranden dem som krysser den, herav Denings tittel Beach Crossings. Hjemvendte sjøfarende har del i en annen virkelighet enn dem som ble hjemme. Aldri helt reintegrerte, forblir de merket av å ha krysset stranden.

Et blikk på kartet forteller hvorfor strandens kulturhistorie i Europa er lang. Relativt begrenset i utstrekning har kontinentet få områder som ligger langt fra saltvann, og de fleste av Europas moderne nasjoner har kystlinje. For de historiske middelhavskulturene var stranden helt avgjørende ettersom vannveiene var de viktigste transportårene. Fra Egypt og Fønikia, via 
det attiske forbund og Roma, til Venezia og Genova, var statsdannelser rundt Middelhavet sterkt knyttet til maritim makt. Derfor var kontroll over strendene avgjørende. Strender var havner, handelssteder og scener for konflikt og krig. Det er en velkjent, men overraskende lite fremhevet kjensgjerning at den europeiske litteraturen innledes med en fortelling som utspiller seg på strendene utenfor en by i Lilleasia. Men de førmoderne kulturene var heller ikke helt ukjente med strandens mer behagelige forlokkelser. For selv om badekulturen hører hjemme i moderne tider, er strandens estetiske kvaliteter ofte gjenstand for refleksjon i romersk filosofi og diktning.

Den stranden vi er fortrolige med i dag, er imidlertid et fenomen av relativt ny dato. Som litterært og malerisk objekt går dens historie tilbake til 1600-tallet, og den løper slik stort sett sammen med den filosofiske estetikkens historie. Historisk sett lå strender utenfor byene og falt gjerne under kategorien ødemark. Lenge før Taussig betegnet de franske klassisistiske forfatterne stranden for le désert. Ikke desto mindre var den arbeidsstedet for dem som var i den nedre enden av den sosiale rangstigen, som fiskere og skjell- og tangsankere. Dette endrer seg på 1600-tallet når den blir et utfartsmål i egen rett. Det er i Europas første strandresort i Scheveningen utenfor der Haag at strandsceneriet oppfinnes som en egen malerisk genre. I Nederland, Frankrike og England etableres gradvis en urban forestilling om stranden som et jordisk paradis, et asyl fra bylivets miasmer. I tråd med dette lar i 1671 jesuitten Dominique Bouhours, le-je-ne-sais-quoi-estetikkens opphavsmann, sine dialoger om kunstopplevelsens ikke-begrepslige karakter, Les Entretiens de Ariste et Eugène, utspille seg i strandsonen med utblikk over et omskiftelig hav (3-27). Stranden er her mer enn et retorisk allmennsted, hos Bouhours er den også et skjønt sted, et sted for fredelig retrett fra verden. Stranden faller slik inn under det som den poetologiske tradisjonen etter antikken omtalte som et locus amoenus, "et yndig sted", et sted hvor det er godt å være.

I den første urbane interessen for stranden - utførlig kartlagt av den franske historikeren Alain Corbin i Le Territoire du vide. L'Occident et le désir du rivage 1750-1840 - møtes mangslungne og sammensatte drivkrefter hvor helse og estetisk opplevelse hører til blant de viktigste. Den amerikanske historikeren John R. Gillis - representert i dette nummeret med et utdrag fra 
The Human Shore - karakteriserer i forlengelsen av Corbin den badekulturen som oppstår mot slutten av 1700-tallet, som oppdagelsen av "den terapeutiske stranden" (Gillis 142). Strandlivets og badingens helsebringende virkning settes for første gang på dagsordenen av opplysningstidens profylaktisk orienterte medisin, hvilket etter hvert også blir en viktig del av grunnlaget for 1800-tallets borgerlige strandkultur. I og med denne fremvoksende strandkulturen hører stranden opp med å være ukultivert og ugjestmild og monstrøs og farlig når stormene slår inn -, snarere symboliseres den nå som en tidslomme. Den blir stedet for helsebringende bad og spaserturer i godt vær, og i uvær også et sted for å oppsøke dramatiske hav, estetiske naturskuer. Hermed rekontekstualiseres i realiteten strandens inhumane sider, og antropologens ødemark og estetens natursceneri er ikke lenger motsetninger, men lar seg forbinde. Skjønt den borgerlige strandutflukten som hyppig skildres i borgerlige romaner fra det nittende århundret, utspiller seg ikke bare i kontrast til en estetisert natur, men også mot et bakteppe av sosial klassedeling. De som fortsatt har sitt utkomme på stranden, inngår - eksplisitt eller ikke - som nødvendig element i de miljøskildringer som lar konturene av borgerens frie tid, sosiale status og verdi tre frem.

Strender har i den europeiske kultursfærens de siste to hundre årene tjent som arena for den frie tidens ørkesløse gleder, og tilfluktssted fra storbyenes støy og jag. Den fritid og de estetiske gleder de gir rom til, er ikke desto mindre sosialt preget. Strender har innebygget i seg politiske og økonomiske realiteter sterkt knyttet til både eiendomsforhold og historiske klasseerfaringer som gjennom den moderne strandkulturen har blitt allmenn- og alminneliggjort og dermed transformert. Kompleksiteten i denne realiteten blir åpenbar når man tar i betraktning at de fleste europeiske kystnasjonenes strender er unndratt den private eiendomsretten, stranden anses gjerne som allmenning og fellesgode. ${ }^{1}$ Dette er en av grunnene til at Europas strender i høy grad er åpne både for fellesaktiviteter og individuell

1 Frem til de siste ti årene hvor bygg- og anleggsindustrien har utøvd et økende trykk på de kystnære områder, se https://www.dr.dk/nyheder/politik/s-forhindrer-bred-aftale-om-liberalisering-af-planloven. https://www.aftenposten.no/ kultur/i/zGWlb1/norske-strender-blir-privatisert-knut-olav-aamaas. 
livsutfoldelse. Når stranden slik forvaltes som et delt estetisk objekt, blir den bokstavelig talt til et locus communis, et sted for alle. Den borgerlige arkitekturens strandpromenader, den realistiske romanens fiskere og fyrvoktere, impresjonismens skildringer av Normandie-kysten, kinofilmenes badelivscener eller amerikansk populærmusikk bærer alle vitnesbyrd om dette. Denne estetiske forhistorien er forutsetning for og bakteppe til det retoriske potensialet i fremstillingen av det 21. århundrets strender, ikke minst for deres utopiske potensial som hverdagsarenaer som tillater en annen virkelighet - "heterotopier" som Michel Foucault kalte dem - eller i form av drømmer om et slaraffenland bortenfor historien og samfunnet. ${ }^{2}$

Historikernes og antropologenes studier demonstrerer at strandens tidløshet kun er tilsynelatende, som realitet har den sin egen historie, sin egen sosiologi og økonomi - og dette i såvel fysisk som i symbolsk forstand. Slaraffenlivet er kun én form for realisering av stranden; strender kan også være fylt med fare og risiko. Som et fristed utenfor sivilisasjonens orden og rutine, har stranden også vært en liminal sone, en arena for møter med det utenfor, enten som et sted for handel, som et ankomststed for uønskede gjester eller til og med for monstre fra et ukjent hav, kort sagt et rom underlagt andre former for lov og rett enn terra firma. Når Steven Spielberg i filmen Jaws i 1975 kapitaliserer på at stranden er landjordens grense mot et usikkert og farefylt hav, står han i en lang tradisjon. Nesten nøyaktig 300 år tidligere, i det franske teaterets kanskje mest berømte stykke, Jean Racines Phèdre fra 1677, dreper et monster fra havet den unge helten Hippolyte mens han driver sine hester langsetter stranden. Og om stranden lenge var fiskernes og sankernes arbeidsplass og kilde til inntekt, og hvor uventet rikdom kunne flyte i land i form av vrakgods, var den også et sted hvor dønningene etterlot døde fisk, dyr og mennesker. Selv om skipsvrakene som tidligere lå langsetter de nord-atlantiske kystlinjene, i dag stort sett er fjernet eller brutt ned, var disse lenge minner om de farene som lå umiddelbart utenfor strandkanten.

2 Michel Foucaults “Des espaces autres", opprinnelig radiokåseriet "Les hétérotopies" kringkastet av Radio France i 1966, utgitt i Le corps utopique; suivi de Les hétérotopies, Paris, Éditions Lignes, 2009. 
Det burde fremgå av det foregående at det kulturhistorisk sett kun i begrenset forstand er meningsfullt å snakke om "stranden" rett og slett. Dette gjelder ikke mindre rent geologisk eller naturhistorisk. Middelhavets strender skiller seg fra Nord-Europas, fysisk, geologisk så vel som biologisk. Tidevannsforskjellene er ubetydelige sammenlignet med Atlanterhavets, og antikkens verden var ukjent med fenomener som stormflo, lange grunner og dønninger. Kystlinjene i Nord-Europa er dessuten i langt større grad preget av silt, grus, stein og berg, sandstrendene utgjør unntakene. Endelig innebærer tidevann og geologi forskjellige livsvilkår; sukkertang (kelp) finnes slik stort sett i kystnære strøk i Atlanterhavet og Stillehavet, ikke i Middelhavet.

Enhver strand er topografisk bestemt som et område som jevnlig overskylles av vann, som omtales som tidevannssonen. Slik er strender i eminent forstand "kronotoper", det vil si steder som ikke kan begripes uavhengig av de temporaliteter og de aktivitets- og handlingsrom som følger av deres fysiske organisering. Denne spatio-temporale realiteten legger premissene for de forskjellige livsformene strendene gir rom til, og de sosiale og kulturelle realitetene de uttrykker økonomisk, juridisk og estetisk - herunder som setting for estetisk bearbeidelse i form av topos, motiver og plottstrukturer, som var det litteraturforskeren Mikhail Bakhtin hadde i tankene da han i en helt annen sammenheng preget kronotop-termen (Bakhtin).

Et uttrykk for strendenes fysiske mangfold er den for et fremmed øre trolig paradoksalt klingende norske geologiske termen bergstrand. Men også H.C. Andersens linje "Du danske friske strand" er en påminnelse om at strender ikke nødvendigvis er ørkener. Kontrasten mellom Andersen og Taussig røper forskjellige nasjonale utblikk, ikke bare hva angår den geologi som utgjør referansepunktet, men også for fortolkningen av den. Kanskje henger Taussigs blikk for strandens karakter av ødemark sammen med at "Beach" ifølge Oxford English Dictionary, også er navnet på en type stein eller stor grus. Skjønt mangfoldet i de europeiske språk for å betegne "strand", så som beach, shore, strand, sands, så vel som plage, grève, rivage, estran, viser ikke kun til geologiske realiteter, men også til de forskjellige formene for livsutkomme de geologiske realitetene gav grunnlag for, de er historiske spor etter måten stranden har blitt brukt på. 
Forskjellene i de materielle vilkårene, strendenes geologi og biologi, har gitt opphav til forskjellige slags kyst. Antropologen Tim Ingold gjør det poeng at stranden historisk alltid vært et taskscape hvor hverdagen har utspilt seg i et utall varianter (Ingold). The work of culture er mer enn den rent symbolske bearbeidelsen av stranden, det uttrykker seg materielt i alt fra kaier og båtslipper via pirer og badehus og til restauranter og dusjanlegg. Men den nordeuropeiske kystlinjens strender er i dag i hovedsak sceneri og ikke lenger en arena for arbeid - til tross for sporadiske nyheter om druknede fremmedarbeidere på østerssanking. I den grad strendene inngår i økonomiske kretsløp, er det som fritidsområde og arena for familieutflukter, fritidsaktiviteter eller narsissisme. Denne refunksjonaliseringen er i dag i bestemmende for deres fysiske realitet.

Kunsten og litteraturen en en viktig del av strandens historie. Den europeiske diktningen begynner på Trojas strender og den oversjøiske litteraturen med de spanske erobrernes landnåm av fremmede kyster. Den strandede sjømannen som redder seg fra stormen, er både en kristen figur og en kjent formel fra det borgerlige romanuniversets eksotiske realisme. Dikteren som kontemplerer det sublime havet, er en romantisk standardfigur, mens stranden som mål for den reisende som krysser kontinentet, er en velkjent klisjé fra reiseromanen. Da kurstedene gjorde stranden til et helsebringende sted, ble også aktivitetene til dem som bodde der, eller fant sitt utkomme på stranden, et estetisk skue. Det kunne ta form av familieidyll som hos Skagen-malerne, som lett tilslørt homoerotisk pornografi hos nord-europeiske efebe-malere i Italia, eller i en av de mange realistiske fiskerromanene i kjølvannet av Victor Hugos Les Travailleurs de la mer. Men få kulturelle aktører har øvd mer innflytelse på det tyvende århundrets strandidealer enn amerikansk kulturindustri og Hollywood. Stillehavets hvite sandstrender, ofte eksotisk danderte med palmetrær, har med filmer som The Mutiny on the Bounty via The Beach Boys til serier som Baywatch preget stereotypier for ikke å si internasjonale kvalitetsstandarder.

Massemedienes oppdagelse og bruk av den nye verdens strender har hatt en avgjørende betydning i konstitusjonen av den moderne stranden. Og selv om den historiske dimensjonen også her er kompleks og strekker seg helt tilbake til oppdagelsen av Sydhavet og polynesernes erotiske frilyn- 
ne på det senere 1700-tall, har den amerikanske vestkystens beach culture fra etterkrigstiden nok vært en av de viktigste impulsene i den sosiale og økonomiske refunksjonaliseringen av stranden, eksemplarisk uttrykt i den globale masseturismens kolportering av idealet om hvite sandstrender - et geologisk fenomen som er betydelig mer utbredt i den nye verden enn i den gamle. Alle de store mytologiske strendene fra det sene tyvende århundret ligger utenfor Europa, om det så dreier seg om Venice Beach, Waikiki Beach, Bondi Beach eller Copacabana.

Om det 21. århundres strand lever opp til den franske sosiologen Jean Baudrillards lett beryktede samtidsdiagnostiske begrep simulacrum - massemedias alltid-allerede ferdigredigerte idealbilder av ikke-eksisterende modeller - utgjør dens paradisiske forlokkelser ikke desto mindre resonansbunnen for den aktuelle politiseringen av stranden, om denne nå er av økologisk eller migrasjonsmessig art. Slik forente i august 2019 en leder i The Economist de to kontrære plottene "apokalypse" og "idyll" i overskriften "A world without beaches". Det som bekymret avisens talerør, var at mange av dagens strender om åtti år vil, om ikke å bli et oppløpsfelt for apokalypsens fire ryttere, så i alle fall befinne seg under vann. ${ }^{3}$ At en stadig økende del av verdens befolkning lever ved kysten, gjør frykten for stigende havnivå ytterst berettiget.

Nå er apokalypsen og idyllen, både som plottstrukturer og troper, velkjente historiske formler med bibelsk tyngde, som illustrerer hvordan den økokritiske diskursen nødvendigvis trekker på det den tyske litteraturhistorikeren Hans Naumann i sin tid kalte for gesunkenes Kulturgut. Med tsunamien i Indiahavet i 2004 ble både Bibelens apokalypse og Atlantis' undergang mobilisert. Man slipper således ikke fra fortidens kulturelle overheng selv i analysen av de mest prekære aktuelle problemer. Tropene og plottene er individuelle ryggmargsreflekser, men utgjør også veven i intertekstualiteten som går forut for og muliggjør et ordskifte. Hvordan disse refleksene mobiliseres, viser seg ikke minst i reaksjonene på de seneste årenes strøm av migranter over Middelhavet. I kommentarfeltet til

3 https://www.economist.com/leaders/2019/08/17/one-way-or-another-thedeluge-is-coming 
en av videoene på YouTube påpekes det i en av postene at det mest "ser ut som en invasjon". Om man suspenderer den politiske tolkningen av utbruddet, er det åpenbart at kommentaren har identifisert en sammenheng mellom visuelle sjablonger etablert av amerikanske krigsfilmer - USAs krig i Stillehavet under andre verdenskrig utfoldet seg primært på eller i den umiddelbare nærhet av strender - og den aktuelle reportasjen. I det vestlige Middelhavet går den historiske parallellen sågar lenger tilbake, i første omgang til berberstatenes strandhogg på jakt etter slaver, og i neste omgang tilbake til antikken hvor piraters røvertokter på land er et fast motiv i hellenismens greske romaner. Også bildene av den tre år gamle druknede syriske gutten, Aylan Kurdi, som for få år siden ble spredt verden over, inngår slik i en eldre erfaringsverdens bilder; strandvaskerne forsvant stort sett med treskipene.

Som patosformler står tradisjonens figurasjoner, troper og klisjeer til rådighet både for innvandringens motstandere og dens tilhengere, for klimaendringsfornektere som økologer. Analysen av deres retoriske funksjonsmåter, den måten de etablerer og produserer ethos, patos, og logos på, er en viktig kulturkritisk oppgave. Patosformler er som den franske kunsthistorikeren Georges Didi-Hubermann argumenterer for, mer og annet enn patetisk dekor ment til å vekke følelser; de er som Aristoteles' bestemmelse av begrepene signaliserer, også bærere av kunnskap, logos, og de maner oss til handling, etos (Didi-Hubermann). For igjen å minne om Levi-Strauss, kan de være velegnet til å tenke med. Samtidig er det verdt å spørre om i hvilken grad disse formlene legger begrensninger på vår forståelse, fungerer ideologisk, det vil si kun bekrefter det vi allerede vet.

Om et knippe kulturelle uttrykk lenge har preget stranden, så bærer disse en bagasje det kan være verdt å utforske. Det betyr imidlertid ikke uten videre at de ikke skulle kunne brukes til å generere ny viten. Her finnes det mye å hente i samtidig kunst og litteratur, ikke minst den som står litt i avstand fra hovedstrømningene, slik som hos kunstnere fra marginene av den vestlige tradisjonen som fra Afrika, Karibia, eller Stillehavet har kartlagt og eksperimentert med egne og annerledes tradisjoner, og, i en rekke tilfeller, også med hvordan disse tradisjonene kan settes i dialog med eller sågar bringes i konflikt med den store tradisjonen. 
Den norske essayisten og forfatteren Espen Stueland spurte i forbindelse med sitt økokritiske essay 700-årsflommen om "skjønnlitteratur kan være en plattform for kritisk bevissthet" - et fruktbart spørsmål dersom vi mener at skjønnlitteraturen på sine estetiske og retoriske premisser kan gi tilgang på hvem vi har vært, er og vil være (15). For om de aktuelle politiske, økonomiske og økologiske kontroverser som blir manifeste på verdens strender - om det er håndheving av nasjonsgrenser, privatisering eller forurensning - er avhengige av de data som skaffes til veie av sosiologer, økonomer eller biologer, så kan litteraturen og kunsten oppvise en strandhistorie som ikke bare er konvensjonell og konformistisk, men også refleksiv, kritisk og eksplorativ overfor denne komplekse, multifunksjonelle grensesonen. Kort sagt, litteraturen og kunsten rommer et knippe med strandhistorier om både reelt eksisterende og mulige strender. Det er nedslag i disse dette nummeret av K\&K - Kultur og klasse presenterer i en rekke artikler som rommer aktuelle teoretiske vinklinger på den litterære strand.

Strandsonens naturhistoriske realiteter er uløselig filtret sammen med dens kulturhistorier. Dens aktualitet var eksplisitt integrert i det historiske, for ikke å si genealogiske blikket som styrte utlysningen etter bidrag til dette nummeret av $\mathrm{K} \& \mathrm{~K}$. Vi fikk god respons, skjønt med en klar overvekt av litterære eller litteraturhistoriske studier. Like fullt spenner bidragene bredt og vitner således om strandens kompleksitet som kulturell realitet. Vi har derfor valgt ikke å redigere nummeret utfra en tanke om at det finnes én strandens historie eller at det skulle være ønskelig å skrive en sådan. Ettersom artiklene fordeler seg over forskjellige perioder og geografier, har vi organisert dem ut fra den meste arbitrære av de hegemoniske kulturelle logikker, alfabetet.

Frits Andersen tar for seg en av den moderne strandens viktigste modeller, Sydhavets strender. "Den allerede moderne strand. Robert Louis Stevensons stillehavsfortællinger" setter søkelyset på strandens funksjon som politisk og økonomisk liminal sone, et rom for forhandlinger og identitetstransformasjoner. Artikkelen kartlegger et spesifikt romlig og temporalt problem som hefter ved stranden som et topografisk og retorisk topos. I kontrast til den romantiske tanken om stranden som et temporalt 
refugium bortenfor storbyenes modernitet, tegner Stevensons fortellinger om akterutseilte beachcombers på fjerne Stillehavsøyer et overraskende bilde av stranden som et slags post-imperialistisk simulasjonsrom basert på spekulasjon og risikotaking. Supplement til ideen om stranden som tilfluktsted fra sivilisasjon er den permanente skuffelsen over aldri å finne idealstranden, som igjen omsettes i nok en velkjent moderne figur, reisen fra en strand til den neste i en endeløs jakt - Alex Garlands The Beach er et kjent nyere eksempel. Hos Stevenson er derimot denne proleptiske retorikken reversert: Oppsiktsvekkende nok er stranden hos ham alltid-allerede moderne; desto lenger vekk fra metropolen, desto mer moderne er den. Stevensons fortellinger leses som en kritikk av det romantisk-moderne topos om stranden som et locus amoenus hinsides tid og rom. For Stevenson er stranden ikke gjenfødselens sted, men et sted som derimot eksisterer mot en horisont av apokalypse og nær forestående undergang.

Katrine Helene Andersen tar i "Nydelsesturisme in extremis. Fra otium til masseturisme på de spanske strande" utgangspunkt i hvordan masseturismen til Spania etableres som en følge av Franco-regimets beslutning om å bruke kystlinjenes kvaliteter til å lansere Spania som en turistdestinasjon. Årsakene var som så ofte ellers i politikken av pekuniær karakter, hvilket fikk regimet til å gå på akkord med sine konservative katolske verdier. Artikkelen kartlegger hvordan de spanske strendene blir åsteder for møter mellom spanjoler og de utenfrakommende, og hvordan den økende tilstrømmingen av turister ikke bare førte til omfattende endringer i infrastruktur, men også til en rekke kulturelle transformasjoner. Spansk og internasjonal litteratur både kartla og bidro til den symbolske behandlingen av det nye strandlivet som vokste frem, hvilket forfatterskap som Carmen Laforet, Juan Goytisolo, Ernest Hemingway, James Michener og J.G. Ballard bærer vitnesbyrd om. Den spanske strand ble utover 60- og 70-tallet synonym med hedonistisk nytelse og sensualitet på et vis som uvegerlig stod i kontrast med de politiske realiteter i Francos Spania. Strandens kulturelle og sosiopolitiske realitet i Spania i dag lar seg imidlertid ikke løsrive fra dens litterære liv og etterliv, argumenterer Andersen.

I "Sous la plage, les pavés! Stranden mellem utopi og dystopi i nyere amerikansk litteratur" oppstiller Tore Rye Andersen et prestisjetungt ameri- 
kansk makkerpar, Thomas Pynchon og Cormac McCarthy. Både Pynchons Inherent Vice (2009) og McCarthys The Road (2006) kretser om stranden som sted og forestilling. Begge romanene etablerer i utgangspunktet et bilde av stranden som et utopisk rom som hovedpersonene drømmer om og søker, og i begge viser den lovede utopien seg å være en dystopi. Denne bevegelsen kan umiddelbart synes å være i tråd med den utopiske impulsens fallende konjunkturer i den senmoderne kapitalismen. Via en komparativ analyse av Inherent Vice og The Road, og i kritisk dialog med utopiteoretikere som Frederic Jameson, Miguel Abensour og Tom Moylan, drøfter Andersen de dynamiske relasjonene mellom utopiske og dystopiske scenarier i begge romaner mot et større bakteppe av strandens funksjon som litterært topos i det 20. århundrets anglosaksiske litteratur.

Susanne Bangert tar i den "Danske friske strand" for seg 1800-tallets landskapsmaleri og dets plass og rolle i konstruksjonen av det typiske danske landskap: bløte bakker, bøketrær, et glimt av vann, og fortrinnsvis lokalisert til Nordsjælland. Denne definisjonen av landskapet fungerer stadig, hevder Bangert, og underbygges løpende av store utstillinger om Guldalderen, som perioden sigende betegnes i dag. Et lite påaktet faktum er at denne konstruksjonen av en ideell nasjonal geografi har hatt fysiske effekter ved at den har preget utformingen av det danske landskapet helt frem til i dag. Den estetiske idealiseringen har fremdyrket en særlig landskapets identitet som har bidratt til å bygge en felles oppfatning av hva som er den typeriktige danske natur og geografi. Idealiseringer har også den effekt at de forenkler. Når forenklinger gjøres til prinsipper for landskapsforvaltning, fører de til fravalg av naturtyper og geografier som ikke kan passes inn i idealkonstruksjonen, altså i realiteten til en likeretting av de kystnære landskapene.

Peter Seeberg er blant de forfatterne som har skrevet en hel roman som utspiller seg i strandsonen, og Jeppe Barnwell setter denne under lupen i "Livets mening på Lakolk strand. En horisontal fordomsfrihed i Peter Seebergs roman Ved havet". Det er en roman uten en hovedperson, dog uten heller å være en tradisjonell kollektivroman. Snarere enn å skildre et felleskap gir den stemmer til en vrimmel av individer som bader, leker, hviler eller driver om i mindre grupper, to og to eller en og en. Romanens ytre handling er minimal, men den er langt fra begivenhetsløs. I fraværet av 
en sentral og bærende handlingstråd tar mange små, individuelle historier form, og den kan derfor karakteriseres som en pluralistisk roman som med stranden som et avgrenset, men allikevel labilt rom tillater en lang rekke forskjellige stemmer og synspunkter. Barnwells utlegning gir en detaljert nærlesing av romanens skildring av livet på Lakolk strand på Rømø, men gjør også avstikkere til et upublisert, hittil ukjent essay av forfatteren selv, to dikt av Paul Verlaine og Charles Baudelaire, samtidig som det trekkes paralleller til samtidige filosofer.

Christian Dahls "Ét sted, to topoi. Stranden som blindgyde og kontaktzone i græsk antik digtning" fokuserer strandens begynnelser i den europeiske litterære tradisjonen, den greske antikken. Av åpenbare historiske og geografiske grunner vrimler den greske litteraturen med strender. Sjøfart omtales av de langt fleste greske forfattere på tvers av epoker og genre. Fordi grekerne stort sett foretrakk å seile langs kysten fremfor å krysse det åpne havet, finnes det et vell av omtaler av stranden som et sted for landgang, for handel, for opphold, og ikke minst for lengsel etter dem som har reist. Allerede hos Homer møtes fastboende og reisende på stranden, den er lokalitet for ritualer og ofringer, men også for grillfester, sportsstevner og kampscener. Ikke desto mindre krystalliserer fremstillingene av dette mangfoldet seg over tiden i et mer begrenset knippe litterære topoi, som inngår som faste elementer i tradisjonen. Artikkelen fokuserer i særlig grad på to strand-topoi som har en sentral plass i gresk litteratur, stranden som møtepunkt og stranden som grense og eksistensiell blindgate. Disse to vidt forskjellige topoi forfølger Dahl både i deres litterære og deres litteraturhistoriske betydning, og han avrunder med å vise hvordan de kan etterspores helt frem til en samtidsforfatter som Derek Walcott.

Knut Ove Eliassens "Strandens topologier" er et forsøk på å kartlegge noen av de forskjellige estetiske og litterære topoiene som mobiliseres i den aktuelle økologiske, politiske og økonomiske interessen for stranden. Med utgangspunkt i Ernst Robert Curtius' topos-teori og Tim Ingolds begrep om taskscape analyseres et knippe etablerte strandtopoi i lys av de praksiser de både reflekterer og har gitt rom til. Mangslungen og ofte konfliktfull oppviser strandens kulturhistorie en lang rekke ofte motstridende topoi; det er alltid tale om strender i flertall. Mer enn en kompleks historisk kon- 
struksjon, er det som i en gitt sammenheng gjelder som "stranden" også et produkt av strandens fysiske realitet, dens status som grense. Strender er verken kun ekotoner (et sted hvor to forskjellige økosystemer møtes, landet og havet) eller kulturfenomen, men et klart eksempel på natur-kultur-hybrider. Den overordnede ambisjonen er å vise hvordan "stranden" på eksemplarisk vis tydeliggjør kompleksiteten i de utfordringer som det antropocene stiller oss overfor. Om problemene med forvaltningen av vår tids strender skal la seg håndtere, om det dreier seg om forbruk, fritid eller forurensning, må de tenkes i komplekse helheter og ikke som separate realiteter som kan løses hver for seg.

Marius Warholm Haugen foretar i "Stranden hos Elena Ferrante" en topokritisk lesning av middelhavsstranden i fire verker av den italienske forfatteren: L'amore molesto (1992), La figlia oscura (2006), La spiaggia di notte (2007) og L'amica geniale (2011-2014). Topokritisk tilnærming er her å forstå som en systematisk utforskning av funksjonelle relasjoner i litterære tekster mellom tematikker og geografiske steder for handling. Artikkelen argumenterer for at stranden har en viktig formgivende funksjon i utviklingen av forfatterskapets nøkkeltemaer, knyttet til vanskelige relasjoner mellom mor og datter, kjønnsroller og sosial klasse. Analysen viser hvordan teksten mobiliserer og leker med et sett av kulturelt og historisk betingede forestillinger om stranden: grensesonen, terskelområdet (liminalsonen), frisonen og det temmede og striglede landskapet. Disse forestillingene tjener til å fremstille stranden som et symbolsk ladet landskap, som igjen bidrar til å forme romanfigurenes psykologiske, emosjonelle og sosiale prosesser. Forestillingen om terskelområdet er særskilt sentral, ved at den gjør stranden til et emblematisk sted for Ferrantes tematisering av det uavklarte og mellomliggende.

I "Mellom vrak og strand: vrakberging og liminalitet på Hitra og Frøya på 1700- og 1800-tallet" gjør Sarah Dahle Hermanstad en detaljert studie av strandhistorien til to norske fiskersamfunn ved utgangen av absolutismen. Hun tar utgangspunkt i hvordan stranden praktisk, men også økonomisk og juridisk, er en viktig grensesone i fiskersamfunnenes daglige realitet. Et sted hvor det uforutsigbare og flyktige nærmest blir en regelmessighet, er stranden en skjæringslinje mellom hav og land, en liminalsone mellom det 
trygge og det utrygge, og mellom det livgivende og dødbringende. Denne uforutsigbarheten satte betingelsene for livet ved kysten av Norge i førog tidligmoderne tid og avgjorde hvilke ressurser som var tilgjengelige. I dette bokstavelig talt grenseoverskridende landskapet utførte kystboerne sine daglige aktiviteter. Om stranden er en liminalsone, er den ikke desto mindre utgangspunktet for deres livsutkomme. Her fanget de fisken som stimet inn i fjorden, jaktet selen som svømte langs øyene og sanket rekved som drev inn fra havet. Nå og da kom også vrak av større skip drivende inn til øyene og utløste en hektisk, men midlertidig, bergingsvirksomhet, med nettopp stranden som utgangspunkt, men ofte med lengre juridisk etterspill som brakte provinsen i kontakt med maktens sentrum. For kystboerne på øyene Hitra og Frøya, utenfor Trondheimsfjorden i Norge, skjedde dette minst 40 ganger i løpet av perioden 1716-1832. Ved å se nærmere på og analysere dokumentene disse begivenhetene har etterlatt, kaster Hermanstad lys over kompleksiteten i denne barske topologiske realiteten.

Den moderne stranden ankommer, utvikles og anlegges som et godt sted i den norske romanen på 1900-tallet. I "Den norske litterære stranden - fortsatt et locus amoenus?" undersøker Christopher Messelt i hvilken grad komponenter som grunnes med og traderes fra etableringen av stranden som et godt sted på 17- og 1800-tallet, lar seg etterspore i den norske romanen. På 1900-tallets første halvdel uttrykkes stranden som et sted for bading i vannet og bruning under solen, et sted for lek, rekreasjon og amorøse utfoldelser, hvilket gjør badestranden til en kalibrert utgave av det klassiske topos locus amoenus. Med dette som bakteppe, og gjennom nærlesinger fra tre nyere norske romaner, argumenteres det for at sider ved det som skapte den moderne stranden, fremdeles gjør seg gjeldende, men at vurderingen av denne utviklingen langt fra er entydig. Hyttebygging i strandkanten og kunstige strender kan ses som ytterpunkter i forlengelsen av den rekreasjonstendensen som hele tiden har utgjort den moderne stranden, men som nå oppleves som pågående og kriminelle tendenser. Dette påminner om at "stranden" til enhver tid produseres av ideologiske, politiske, kulturelle, sosiale, teknologiske og økonomiske faktorer. 


\section{LITTERATUR}

Bakhtin, Mikhail M. "Forms of Time and of the Chronotope in the Novel". The Dialogic Imagination. Four Essays. Austin: University of Texas Press, 1981. 84-258.

Bouhours, Abbé. Les Entretiens d'Ariste et d'Eugène. Paris, 1671.

Corbin, Alain. Le Territoire du vide. L'Occident et le désir du rivage 1750-1840, 2. utg. Paris: Flammarion, 1990.

Dening, Greg. Beach Crossings: Voyaging across Times, Cultures and Self. Carlton Victoria: Melbourne University Publishing, 2004.

Didi-Hubermann, Georges. L'Image Survivant. Paris: Minuit, 2002.

Foucault, Michel. Le corps utopique; suivi de Les hétérotopies. Paris: Éditions Lignes, 2009. Gillis, John R. The Human Shore. Seacoasts in History. Chicago: Chicago University Press, 2012.

Ingold, Tim. "The Temporality of the Landscape". World Archaeology, 252 (1993): 152-174. Stueland, Espen. 700-årsflommen. Oslo: Forlaget Oktober, 2016.

Taussig, Michael. "The Beach (A Fantasy)". Critical Inquiry, 262 (Vinter 2000): 248-278. 